\title{
Craniofacial Abnormalities Induced by Ectopic Expression of the Homeobox Gene Hox-1.1 in Transgenic Mice
}

\author{
Rudi Balling, George Mutter, $\dagger$ \\ Peter Gruss," and Michael Kessel* \\ *Department of Molecular Cell Biology \\ Max Planck Institute of Biophysical Chemistry \\ 3400 Göttingen \\ Federal Republic of Germany \\ † Department of Pathology \\ Brigham and Women's Hospital \\ Boston, Massachusetts 02115
}

\section{Summary}

Hox-1.1 is a murine homeobox-containing gene expressed in a time- and cell-specific manner during embryogenesis. We have generated transgenic mice that ectopically express Hox-1.1 from the chicken $\beta$-actin promoter. In these mice Hox-1.1 expression was changed to an almost ubiquitous pattern. Ectopic expression of Hox-1.1 leads to death of the transgenic animals shortly after birth and is associated with multiple craniofacial anomalies, such as cleft palate, open eyes at birth, and nonfused pinnae. This phenotype is similar to the effects seen after systemic administration of retinoic acid during gestation. This suggests that retinoic acid embryopathy and the specific developmental defects caused by ectopic expression of a potential developmental control gene share a common pathogenic mechanism.

Introduction

Antennapedia (Antp), a mutation in the fruit fly Drosophila melanogaster, is characterized by the presence of mesothoracic legs in the place of antennae. The molecular cause for this phenotype is a chromosomal rearrangement placing the Antp gene under the control of a heterologous promoter that transcriptionally activates the gene ectopically in the imaginal discs of the antennae (Frischer et al., 1986). The same phenotype can also be induced experimentally in transgenic flies carrying an Antp gene under the control of a heat shock promoter (Schneuwly et al., 1987; Gibson and Gehring, 1988). Through the analysis of "gain-of-function mutations" like Antp, and complementing "loss-of-function mutations," molecular mechanisms of Drosophila embryonic development have been elucidated. In particular, genes affecting metamerization and segment specification have been identified and cloned (Gehring and Hiromi, 1986; Scott and Carroll, 1987; Akam, 1987; Ingham, 1988).

Many of these Drosophila developmental control genes share conserved DNA sequences, such as homeoboxes, paired boxes, or zinc finger encoding motifs. These motifs are also present in genes of other organisms such as frogs, mice, and humans, and many of the respective genes have been isolated (Holland and Hogan, 1986; Dressler and Gruss, 1988). Evidence that genes with se- quence homology to Drosophila developmental control genes play a regulatory role during mammalian embryogenesis was obtained from the molecular analysis of the mouse mutant "undulated" (un) (Balling et al., 1988), characterized by malformations of the axial skeleton along the entire axis. A point mutation in the murine paired box containing gene $\operatorname{Pax} 1$ (Deutsch et al., 1988) may be responsible for the un phenotype.

One of the main problems in mammalian embryology is the limited number of appropriate mutants, making a functional analysis particularly difficult. However, loss-offunction as well as gain-of-function mutants can be generated using recently developed methods. Specific genes can be inactivated in the genome of embryonic stem cells by homologous recombination. Such mutated alleles can be introduced into mice, and homozygous transgenic animals can be obtained by breeding (Mansour et al., 1988; Thompson et al., 1989). A similar approach has recently been applied to eliminate a functional Hox-1.1 gene from the mouse genome (Zimmer and Gruss, 1989).

In addition, designed genes can be introduced into the genome of transgenic mice to achieve ectopic expression during development, similar to the approach described above for the Drosophila Antp gene under the control of a heat shock promoter. This strategy has been applied in the functional analysis of oncogenes, genes that are important in the establishment of the immune repertoire, or genes that code for multimeric proteins (for review see Jaenisch, 1988).

In the present study we have expressed Hox-1.1 ectopically in transgenic mice using the ubiquitous transcripitional activity of the chicken $\beta$-actin promoter. Transgenic mice with deregulated expression of Hox-1.1 die within a few days after birth. These mice show a striking combination of craniofacial abnormalities, such as open eyes at birth, nonfused pinnae, and cleft secondary palate. This phenotype is very similar to the effects seen after application of retinoic acid during pregnancy (retinoic acid embryopathy, or RAE) and to the previously described mouse mutant "first arch malformation" (far). Based on the similarity between the phenotype of our transgenic mice and both RAE and the first arch malformation phenotype, the possibiliy that Hox-1.1 ectopic expression affects cranial neural crest cells is discussed.

\section{Results}

\section{Production of Transgenic Mice}

A genomic expression vector was constructed (Figure 1) to express Hox-1.1 in transgenic mice. The vector contains a $\mathbf{3 4 0}$ bp promoter fragment of the chicken $\beta$-actin gene fused to genomic Hox-1.1 sequences at a Xbal site located in the $5^{\prime}$ end of the cDNA clone $\mathrm{C} 1$ (Kessel et al., 1987). The Hox-1.1 sequences extend from 500 bp upstream of the translational initiation codon to 300 bp downstream of the poly(A) addition site.

Eleven transgenic mice were identified that carry the 


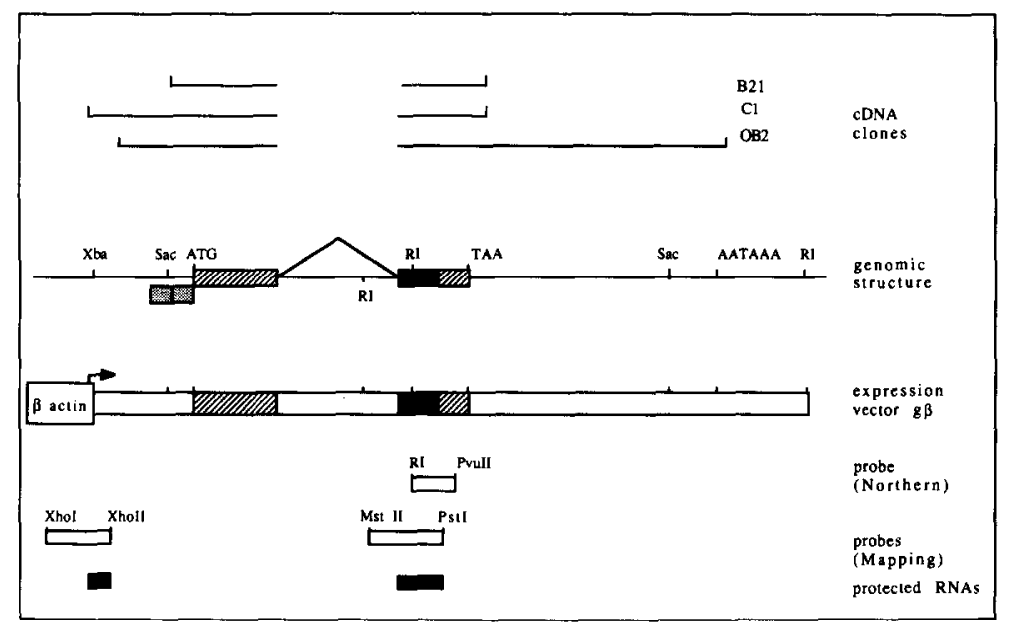

Figure 1. Structure of the Hox-1.1 Transcription Unit and of the Derived Expression Vector $g \beta$

Three types of cDNAs for Hox-1.1 have been isolated and are indicated: B21 from differentiated F9 cells (Kessel et al., 1987), C1 from 3T3 cells, and OB2 from MB66 transformed fibroblasts (M. Kessel, unpublished data). The structure of the Hox-1.1 gene as deduced from the depicted cDNA clones is shown. The main open reading frame is hatched, and the homeobox is a filled box. Two small upstream frames are shown stippled. The $\beta$-actin promoler is fused to genomic sequences at the indicated Xbal site. Details for the construction of the expression vector $g \beta$ are given in Experimental Procedures. RNA probes for the mapping studies were generated from sequence between the Xhol (actin) and the Xholl (Hox-1.1) sites, and between the Msill (intron) and Pstl sites. The protected RNAs are indicated as stippled boxes. The homeobox-containing fragment between the EcoRI and Pvull sites was labeled for the Northern analysis. chicken $\beta$-actin-Hox-1.1 (gß) genomic construct (Table 1). Between one and five copies of the transgene had been inserted into a single integration site (data not shown). Seven out of the 11 transgenic mice died shortly after birth (F0 animals) or were sacrificed when they developed very poorly and survival seemed unlikely (Table 1). Four transgenic mice carrying $g \beta$ survived without any obvious pathological phenotype and were used as founders for establishing transgenic lines. One of the four lines ( $\mathrm{Tg}-\mathrm{g} \beta$ 471) had a rearrangement in the Hox-1.1 transgene, and aberrantly sized RNAs were detected in the brain. Therefore this line was not analyzed further. $F 1$ offspring were produced from the remaining lines $\mathrm{Tg}-\mathrm{g} \beta-747,-938$, and -952. Founder $\mathrm{Tg}-\mathrm{g} \beta-747 \mathrm{did}$ not transmit the transgene, probably as a result of mosaicism. Tg-gB-952 transmitted the transgene; however, no $g \beta$ transcripts could be detected in lung, brain, liver, kidney, uterus, spleen, or liver of $\mathrm{F} 1$ animals (data not shown), so that integration probably occurred into a silent genomic locus. Animal Tg-g $\beta-938$ was healthy and gave birth to ten normally sized litters ( $\mathrm{Ta}-$ ble 2). Although $\mathrm{Tg}-\mathrm{g} \beta-938$ itself showed no abnormalities, all of her transgenic offspring were nonviable.

In all litters from animal $\mathrm{Tg}-\mathrm{g} \beta-938$ we found a strict correlation between transgenicity and postnatal death in the first few days after birth (Table 2). This phenotype was identical to that of the seven transgenic Fo animals that died shortly after birth. The observation that a phenotype caused by a transgene is observed in the F1, but not in the Fo, generation of a particular line has also been described for mice carrying human immunodeficiency virus

\begin{tabular}{|c|c|c|c|c|c|c|c|}
\hline $\begin{array}{l}\text { Foster } \\
\text { Number }\end{array}$ & $\begin{array}{l}\text { Litter } \\
\text { Size }\end{array}$ & $\begin{array}{l}\text { Transgenic } \\
\text { Animals }\end{array}$ & $\begin{array}{l}\text { Animal } \\
\text { Number }\end{array}$ & $\begin{array}{l}\text { Inadequate } \\
\text { Weight or } \\
\text { Size }\end{array}$ & $\begin{array}{l}\text { Spontaneous } \\
\text { Death (time } \\
\text { after birth) }\end{array}$ & $\begin{array}{l}\text { Sacrificed } \\
\text { (time after } \\
\text { birth) }\end{array}$ & Comments \\
\hline 132 & 4 & 1 & 492 & + & 14 days & - & - \\
\hline 162 & 10 & 1 & 597 & + & 3 days & - & - \\
\hline 173 & 5 & 1 & 797 & $+1-$ & $5 \mathrm{hr}$ & - & - \\
\hline 181 & 8 & 2 & $\begin{array}{l}794 \\
795\end{array}$ & $\begin{array}{l}+ \\
+\end{array}$ & $\begin{array}{l}1 \mathrm{hr} \\
-\end{array}$ & $\overline{6}$ days & - \\
\hline 220 & 9 & 2 & $\begin{array}{l}1101 \\
1183\end{array}$ & $\begin{array}{l}+ \\
+\end{array}$ & $\begin{array}{l}1 \mathrm{hr} \\
-\end{array}$ & $\overline{7}$ days & - \\
\hline 122 & 13 & 1 & 471 & - & - & - & $\begin{array}{l}\text { transgene } \\
\text { rearranged }\end{array}$ \\
\hline 170 & 10 & 1 & 747 & - & - & - & $\begin{array}{l}\text { transgene not } \\
\text { transmitted }\end{array}$ \\
\hline 189 & 8 & 1 & 938 & - & - & - & $\begin{array}{l}\text { transgenic } \\
\text { offspring nonviable }\end{array}$ \\
\hline 194 & 3 & 1 & 952 & - & - & - & $\begin{array}{l}\text { transgene not } \\
\text { expressed }\end{array}$ \\
\hline
\end{tabular}




\begin{tabular}{|c|c|c|c|c|c|c|c|}
\hline $\begin{array}{l}\text { Litter } \\
\text { Number }\end{array}$ & $\begin{array}{l}\text { Litter } \\
\text { Size }\end{array}$ & $\begin{array}{l}\text { Transgenic } \\
\text { Animals }\end{array}$ & $\begin{array}{l}\text { Animal } \\
\text { Number }\end{array}$ & $\begin{array}{l}\text { Inadequate } \\
\text { Weight or } \\
\text { Size }\end{array}$ & $\begin{array}{l}\text { Open } \\
\text { Eyes }\end{array}$ & $\begin{array}{l}\text { Spontaneous } \\
\text { Death (time } \\
\text { after birth) }\end{array}$ & $\begin{array}{l}\text { Sacrificed } \\
\text { (time after } \\
\text { birth) }\end{array}$ \\
\hline 1 & 8 & 1 & 1184 & + & ND & 5 days & - \\
\hline 2 & 15 & 4 & $\begin{array}{l}1416 \\
1418 \\
1419 \\
1420\end{array}$ & $\begin{array}{l}+ \\
+ \\
+ \\
+\end{array}$ & $\begin{array}{l}\text { ND } \\
\text { ND } \\
\text { ND } \\
\text { ND }\end{array}$ & $\begin{array}{l}- \\
2 \text { days } \\
2 \text { days } \\
1 \mathrm{hr}\end{array}$ & $\begin{array}{l}1 \mathrm{hr} \\
- \\
- \\
-\end{array}$ \\
\hline 3 & 16 & 3 & $\begin{array}{l}9381 \\
9382 \\
9383\end{array}$ & $\begin{array}{l}+ \\
+ \\
+\end{array}$ & $\begin{array}{l}\text { ND } \\
\text { ND } \\
\text { ND }\end{array}$ & $\begin{array}{l}1 \mathrm{hr} \\
1 \mathrm{hr} \\
1 \text { day }\end{array}$ & - \\
\hline 4 & 17 & 5 & $\begin{array}{l}1513 \\
1515 \\
1516 \\
1520 \\
1526\end{array}$ & $\begin{array}{l}+ \\
+ \\
+ \\
+ \\
-\end{array}$ & $\begin{array}{l}+ \\
+ \\
- \\
- \\
-\end{array}$ & $\begin{array}{l}- \\
- \\
- \\
-\end{array}$ & $\begin{array}{l}1 \mathrm{hr} \\
5 \mathrm{hr} \\
5 \mathrm{hr} \\
1 \text { day } \\
2 \text { days }\end{array}$ \\
\hline 5 & 17 & 4 & $\begin{array}{l}1529 \\
1530 \\
1531 \\
1545\end{array}$ & $\begin{array}{l}+ \\
+ \\
- \\
-\end{array}$ & $\begin{array}{l}+ \\
+ \\
+ \\
+\end{array}$ & $\begin{array}{l}1 \mathrm{hr} \\
1 \mathrm{hr} \\
- \\
-\end{array}$ & $\begin{array}{l}- \\
- \\
1 \mathrm{hr} \\
1 \mathrm{hr}\end{array}$ \\
\hline 6 & 11 & 2 & $\begin{array}{l}1546 \\
1547\end{array}$ & + & - & $\begin{array}{l}1 \text { day } \\
1 \text { day }\end{array}$ & - \\
\hline 7 & 15 & 3 & $\begin{array}{l}9384 \\
9385 \\
9386\end{array}$ & $\begin{array}{l}+ \\
+ \\
+\end{array}$ & $\begin{array}{l}- \\
+ \\
+\end{array}$ & $\begin{array}{l}1 \mathrm{hr} \\
1 \text { day } \\
-\end{array}$ & $\begin{array}{l}- \\
- \\
1 \mathrm{hr}\end{array}$ \\
\hline 8 & 8 & 3 & $\begin{array}{l}1616 \\
1617 \\
1618\end{array}$ & $\begin{array}{l}- \\
-\end{array}$ & $\begin{array}{l}+ \\
- \\
-\end{array}$ & $\begin{array}{l}1 \text { day } \\
1 \text { day } \\
1 \text { day }\end{array}$ & $\begin{array}{l}- \\
- \\
-\end{array}$ \\
\hline 9 & 10 & 1 & 9387 & + & - & 1 day & - \\
\hline
\end{tabular}

ND, not determined.

DNA (Leonard et al., 1988). Several F1 animals were sacrificed for histological and RNA analysis as soon as it became apparent that they would not survive.

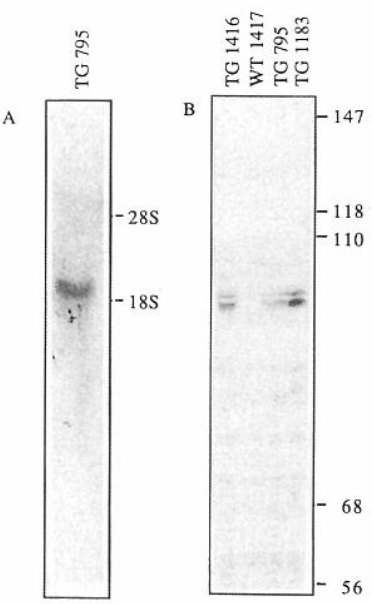

Figure 2. Transgene Expression in Newborn Fo and F1 Animals (A) Northern blot analysis of RNA from animal Tg-g $\beta-795$ probed with a Hox-1.1 homeobox probe.

(B) RNAase mapping of RNAs from the two FO animals Tg-gB-795 and -1183 , and the $F 1$ mice Tg-g $\beta-1416$ and $W T$ 1417, the latter being a nontransgenic littermale.

\section{Expression of the Hox-1.1 Transgene}

RNA from newborn transgenic animals was analyzed for expression of the transgene by Northern blotting and RNAase mapping (Figure 2). Transcripts of the predicted length (Figure 2A) and with the correctly protected chimeric $5^{\prime}$ sequences (Figure 2B) were detected in transgenic $F 0$ animals as well as in the transgenic offspring of Tg-g $\beta-938$. We were unable to detect $g \beta$ transcripts by in situ hybridization.

Line $\mathrm{Tg}-\mathrm{g} \beta-938$ provided transgenic animals for a more detailed analysis of expression and phenotype (Table 2).

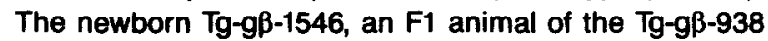
line, was identified initially by lower weight as compared with its littermates; it was sacrificed directly after birth, and RNA was prepared from various organs. Owing to the limited amount of material, RNA was not separately prepared from tissues such as spinal cord and bone marrow. RNA expressed from the transgene was readily detectable in brain, head, stomach, heart, lung, bladder, muscle, rib cage, and cervical and thoracic vertebral columns (Figure 3). The RNA from head tissue was also mapped using simultaneously the transgene-specific and the homeobox probes (see Experimental Procedures; Figure 5B). A comparison of the intensities of the two protected bands indicates that the chimeric RNA is the only RNA species found in the head of newborn Tg-gB-1516. The levels of this RNA and of chimeric Hox-1.7 RNAs in the other 


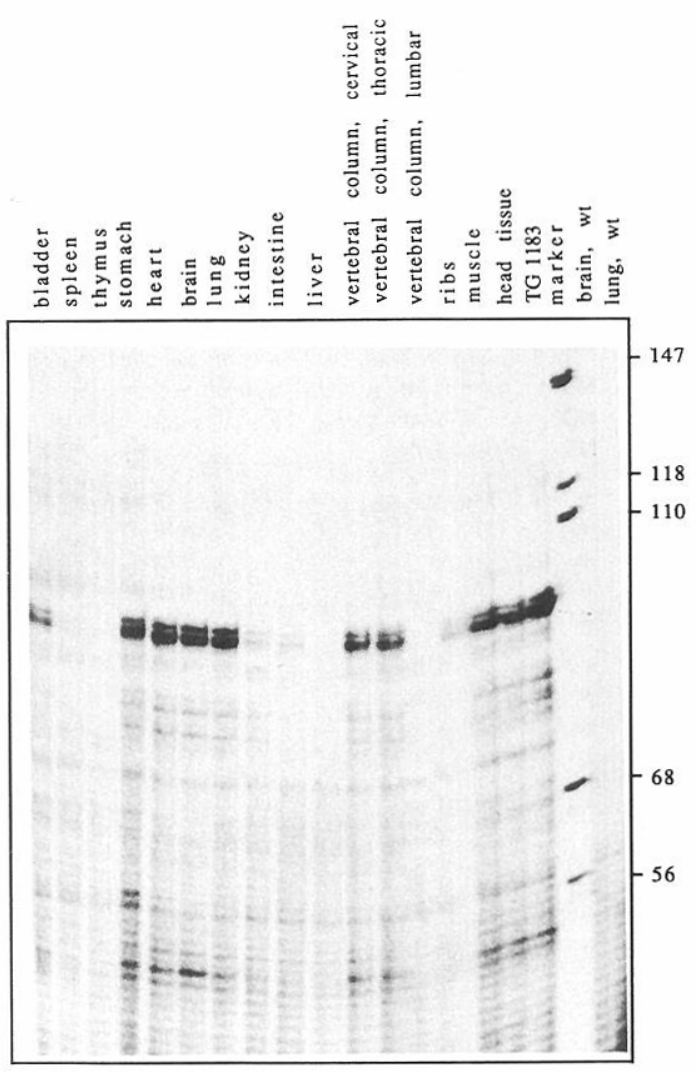

Figure 3. Expression of the Transgene in Organs and Tissues from the Newborn Animal Tg-gß-1516

RNA preparation and RNAase mapping were performed as outlined in Experimental Procedures. The "vertebral column" was dissected out by cutting as near as possible laterally of the vertebrae, and then subdividing the column after the eighth and thirteenth ribs into a cervical, a thoracic, and a lumbar segment. "Rib" tissue was prepared by taking out the entire rib cage. "Head" tissue comprised the head after removal of the brain. As a positive control, RNA from Tg-gß-1183 was mapped in the same experiment; brain and lung RNAs of a nontransgenic littermate were used as negative controls. In all lanes $\mathbf{4 0} \mu \mathrm{g}$ of total RNA was analyzed, with the following exceptions: bladder $(14 \mu \mathrm{g})$, spleen $(5 \mu \mathrm{g})$, thymus $(10 \mu \mathrm{g})$, and heart $(30 \mu \mathrm{g})$.

tissues listed above are still considerably lower than the level of endogenous Hox-1.1 RNA detected in preparations from whole day 12 embryos (Figure 5B). Very low transgene expression was detected in kidney and gut while, notably, the lumbar vertebral column and the liver did not contain g $\beta$ RNA (Figure 3).

Only two transgenic mice were identified that expressed the transgene but did not show a pathological phenotype. Tg-g $\beta-1526$ had been sacrificed 2 days after birth and was identified to be transgenic only after DNA analysis, while transgenic littermates had been readily recognizable by phenotype (Table 2). Transgene expression in brain and kidney and the absence of $g \beta$ RNA in liver indicated a pattern qualitatively similar to that in typical transgenic littermates (Figure 4A). Tg-g $\beta-938$, the only transgenic animal that produced expressing offspring, was sacrificed after giving birth to ten litters (Table 2). Analysis of $g \beta$ RNA revealed detectable levels in lung, heart, brain, stomach, and bladder, very low levels in kidney, gut, and thymus, and no RNA in liver (Figure 4B). A quantitative comparison of the RNA levels in these two animals to RNA from the FO animal $\mathrm{Tg}-\mathrm{g} \beta-1183$ (Table 1 ) indicates a relatively low expression level in the two apparently healthy animals (see also Figure 3). This may explain the survival of the transgenic founder $\mathrm{Tg}-\mathrm{g} \beta-938$.

Since the transgenic animals died shortly after birth, it was of interest to analyze $\mathrm{g} \beta$ expression during embryogenesis. Therefore a series of transgenic mice were generated and $\mathrm{F} 0$ embryos analyzed for $\mathrm{g} \beta$ expression at day 12.5 postcoitum. In two out of eight transgenic embryos we were able to detect expression of the transgene (Figure 5A). A comparison of the RNA amount contributed by the chimeric RNA with the total level of Hox-1.1 transcripts revealed that only very little additional RNA is added by expression of the transgene in embryo $\mathrm{Tg}-\mathrm{g} \beta$ 1621 (Figure 5B). We conclude that the transgene contains sufficient regulatory sequences to be expressed at day 12 of gestation, albeit at a relatively low level, and that the affected animals had transcribed the transgene during embryogenesis as well.

\section{Phenotype of Hox-1.1 Transgenic Mice}

Offspring expressing the transgene were live-born, but died from $1 \mathrm{hr}$ to 14 days after birth. The only exception was animal Tg-g $\beta-938$, which exhibited no pathological phenotype. Those individuals with briefest survival were unable to nurse, as shown by the absence of milk in the stomach. With increasing survival, transgenic newborns experienced poor weight gain and failed to thrive. The animal that survived the longest $(\mathrm{Tg}-\mathrm{g} \beta-492)$ died on day 14 after birth (Figure 6).

In different animals multiple craniofacial abnormalities were noted, such as cleft secondary palate, incomplete eyelid fusion, and detached pinnae (Figures 7-9). In all of these sites there was a deficiency of underlying connective tissues resulting in small palatal shelves, hypoplastic palpebrae, and nonfused pinnae. Exophtalmos, which may secondarily delay eyelid fusion, was not present. A pointed snout, consistent with a poorly formed maxilla, was noted in one of the animals with cleft palate (Tg-g $\beta$ 794, Figure 7).

An F1 transgenic animal ( $\mathrm{Tg}-\mathrm{g} \beta-1530)$ from line $\mathrm{Tg}-\mathrm{g} \beta$ 938 was serially sectioned along with a control nontransgenic littermate for comparison, and stained for routine histological analysis. Particular attention was paid to morphological parameters of visceral maturity and congenital defects. Careful evaluation of the oral and nasopharyngeal region showed cleft secondary palate (Figure 8) without ectopic chondrification of the palatal shelf. The primary hard palate, located rostral to the incisive foramen, was closed, and associated cleft lip was absent. Lung and renal development were age appropriate, indicating that the observed delayed eyelid (Figure 8) and ear fusions are not part of a generalized immaturity. The ocular orbit and retro-orbital structures were normal. The middle and inner ear were unremarkable. Pulmonary infection or aspirated foreign material was not observed. Gastrointestinal defects that might inhibit feeding such as tracheoesopha- 

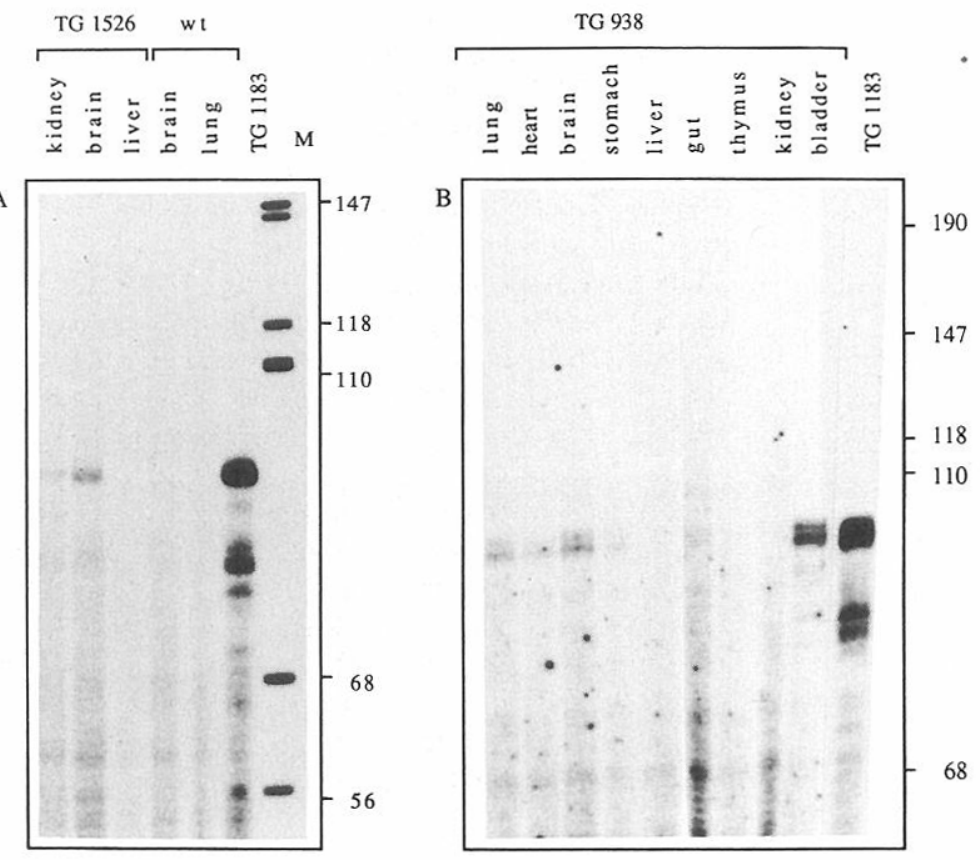

Figure 4. Transgene Expression in Animals with No Obvious Pathological Phenotype

(A) RNAase mapping of total RNA isolated from organs of animal $\mathrm{Tg}-\mathrm{g} \beta-1526$ and of a nontransgenic (wt) littermate. Both mice were sacrificed with no pathological symptoms 2 days after birth. RNA from animal $\mathrm{Tg}-\mathrm{g \beta}-1183$ was used as a positive control.

(B) RNAase mapping of total RNA isolated from organs of the adult animal Tg-gß-938, the only expressing transgenic mouse surviving to adulthood and fertility. RNA from animal Tg-g $\beta-1183$ was used as a positive control.
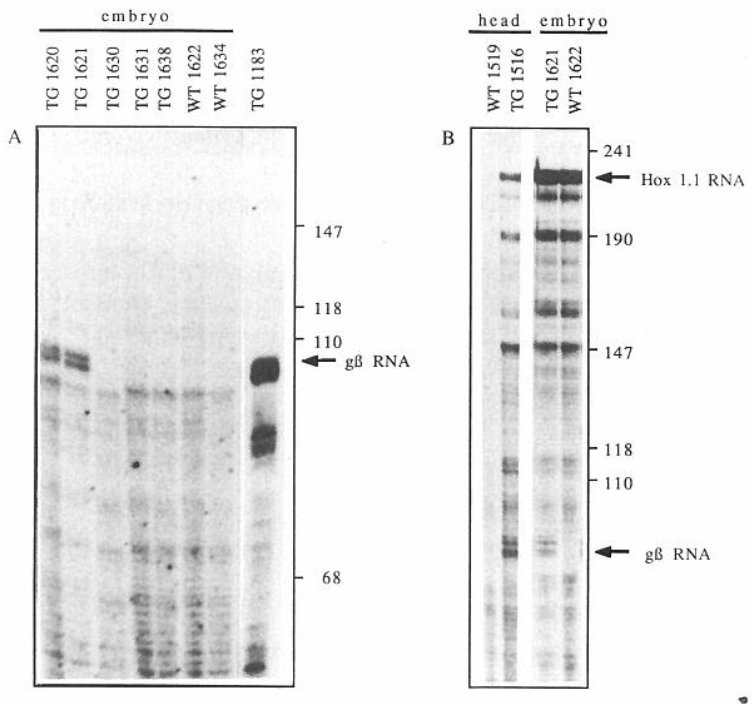

Figure 5. Expression of Transgenic and Endogenous Hox-1.1 RNAs in Embryos and Newborn Head

(A) Expression of the transgene in embryos. The foster mothers were sacrificed at day 12 of gestation. Embryos, yolk sacs, and placentas were dissected out and used for DNA and RNA analysis. RNAase mapping data are shown for five transgenic embryos (Tg-g $\beta-1620,-1621$, $-1630,-1631$, and -1638) and two wild-type littermates (WT 1622 and 1634).

(B) Relative levels of transgenic versus total Hox-1.1 homeoboxcontaining RNAs. The RNAs analyzed in (A) (from the day 12 embryos Tg-gק-1621 and WT 1622) and in Figure 3 (from nontransgenic and transgenic head tissue, prepared from the newborn littermates WT 1519 and Tg-gß-1516, respectively) were simultaneously mapped with the $g \beta$ transgene probe and the Hox-1.1 homeobox-specific probe (see Experimental Procedures). Note that the 214 base protected band (arrow, Hox-1.1 RNA) in the lane from animal Tg-9ß-1516 results from the presence of transgene RNA only, while the corresponding band in the lane from animal TG-gß-1621 is the sum of chimeric plus endogenous RNAS. geal fistula or enteric atresia were absent. The cardiovascular, hepatic, hematopoietic, endocrine, and central nervous systems were unremarkable.

As outlined in Table 2, about $50 \%$ of the transgenic offspring of $\mathrm{Tg}-\mathrm{g} \beta-938$ had one or both eyes open at birth. The extent of eye opening varied from pinhole size to wide open. Not all animals could be evaluated for cleft palate. However, cleft secondary palate was found in three independently produced transgenics: two FO animals ( $\mathrm{Tg}$ g $\beta-794$ and -1101) and an F1 offspring from line $\mathrm{Tg}-\mathrm{g} \beta-938$. From this line five other offspring had a closed palate but an atypical pattern of rugae (data not shown). It is important to note that all three animals with cleft palate also had open eyes at birth. In addition, two of them had nonfused pinnae, whereas the third one was not evaluated for this phenotype.

\section{Discussion}

\section{Endogenous versus Ectopic Hox-1.1 Expression}

To create a gain-of-function mutant by ectopic expression of the murine homeobox gene Hox-1.1, we generated transgenic mice with a chicken $\beta$-actin promoter-Hox-1.1 expression vector. Endogenous Hox-1.1 expression is maximal at day 12 of gestation, when RNA is found in the neural tube, spinal ganglia, and sclerotomes (ColbergPoley et al., 1985a; Mahon et al., 1988). The well-defined anterior borders of expression differ between ectodermally and mesodermally derived tissues. In the neural tube and the spinal ganglia, expression starts at the level of the fourth ganglion, whereas mesodermal expression extends caudally from the second thoracic prevertebra (Mahon et al., 1988). Posterior boundaries are less well defined, and levels of Hox-1.1 RNA decrease toward the 

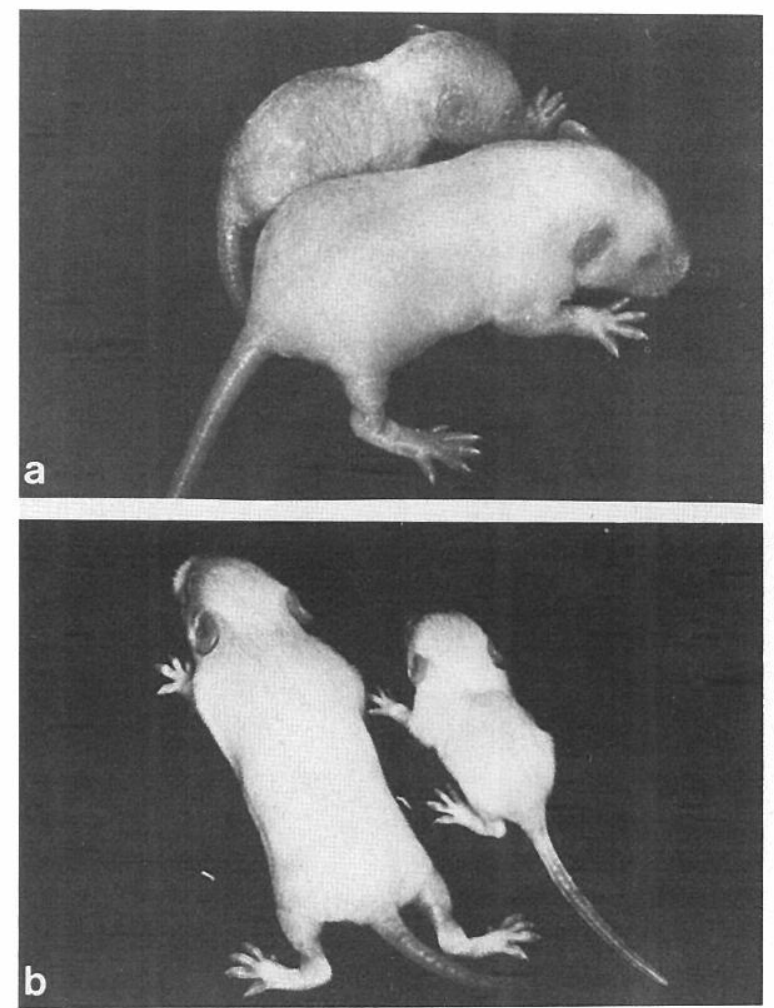

Figure 6. Development of Animal Tg-gß-492 after Birth

The relatively long survival of $\mathrm{Tg}-\mathrm{g} \beta-492$ demonstrates the developmental retardation after birth as compared with a nontransgenic littermate. (a) Five days after birth. (b) Fourteen days after birth.

caudal end of the embryo. At no time in development can Hox-1.1 RNA be detected in the head region (M. Kessel, unpublished data).

The specifically restricted pattern of Hox-1.1 expression in normal mice was changed to an almost ubiquitous expression pattern in the transgenic mice. The observed expression of the transgene results from the ubiquitous activity of the $\beta$-actin promoter. The promoter sequences used for the $\mathrm{g} \beta$ construct are active in a variety of tissue culture systems, including teratocarcinoma stem cells (B. Paterson, personal communication; $M$. Kessel, unpublished data; Guild et al. 1988). The relatively low levels of expression inititiated by the chicken $\beta$-actin promoter may have been a parameter that allowed the animals to survive until birth.

It is likely that additional control regions from the Hox-1.1 sequences influence the expression of the transgene. The presence of two untranslated open reading frames upstream of the initiation codon for the sequence encoding the homeodomain protein may modulate Hox-1.1 translation (Kessel and Gruss, 1988), and a posttranscriptional destabilization signal may be present in the second exon (Colberg-Poley et al., 1987). The postnatal lethality was strictly correlated with the presence and transcription of the transgene. Therefore we conclude that it is the ectopic or ubiquitous expression of Hox-1.1 that causes the observed phenotype.
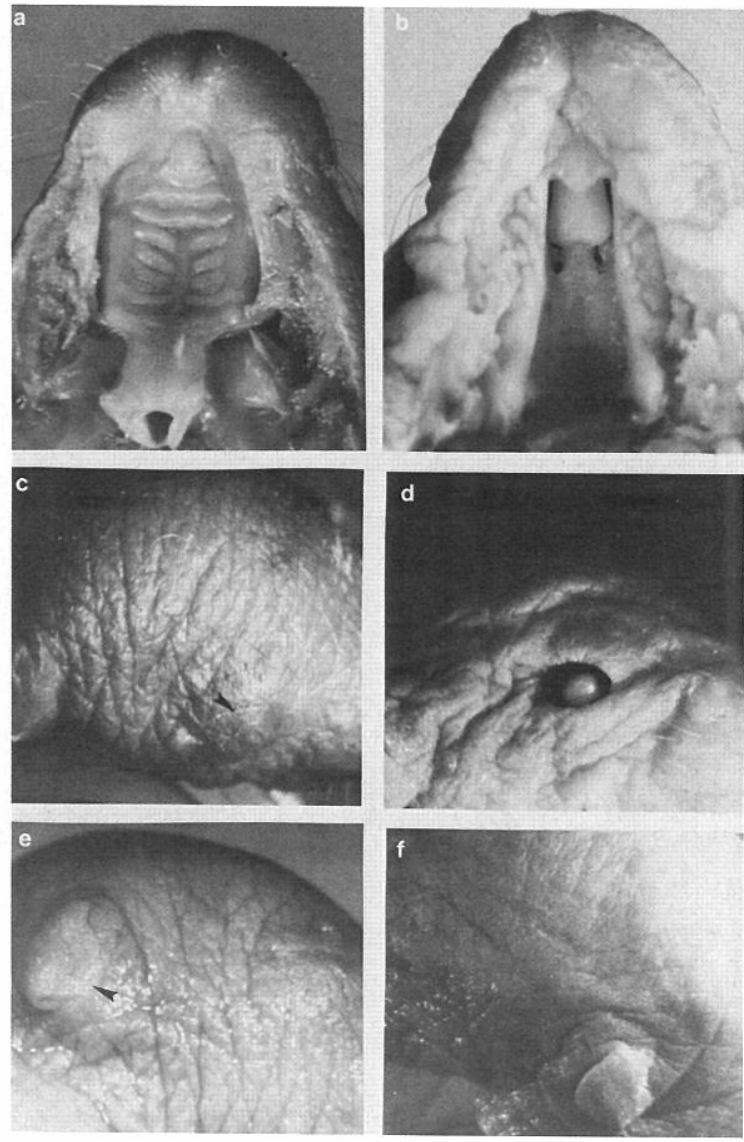

Figure 7. Macroscopic Comparison of Phenotypes from Wild-Type and Transgenic Mice Directly after Birth

(a), (c), and (e) are wild-type animals; (b), (d), and (f) are transgenic animals. The specimens were fixed in Bouin's solution. Mandible and tongue were dissected for viewing of the palatal region.

(a) Palate.

(b) Cleft palate

(c) Fused eyelids.

(d) Open eyes.

(e) Pinna fused to the scalp

(f) Nonfused pinna.

\section{Craniofacial Abnormalities in Transgenic Animals}

Craniofacial abnormalities were detected among the nonviable newborn transgenic animals expressing Hox-1.1 ectopically. Morphological alterations were restricted to the head, which does not normally contain Hox-1.1 RNA at any time of development. At birth, visceral and somatic structures caudal to the head were normally configured, developmentally age appropriate, and without pathological findings. It seems that the majority of the embryonic tissues are well buffered against effects of ectopic Hox-1.1 expression at the level obtained with the $g \beta$ vector. While a cleft palate would be sufficient to explain postnatal lethality, we cannot yet explain the dominant lethal phenotype in animals without cleft palate. Possibilities include functional or metabolic defects not reflected in the morphology of the tissues examined, or structural changes too subtle to be resolved by routine histology.

The observed head abnormalities-open eyes, non- 

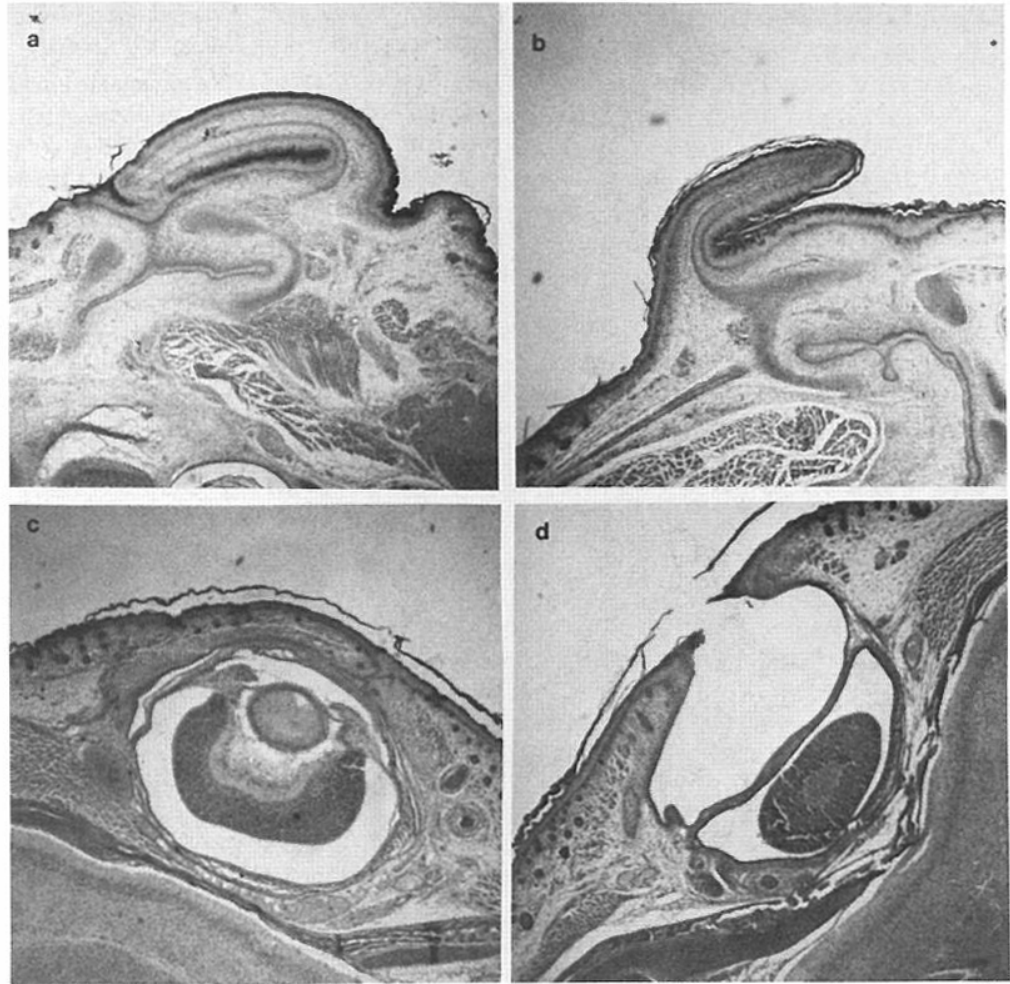

Figure 8. Histological Demonstration of Nonfused Pinnae and Open Eyes

(a) and (c) are sections from a nontransgenic newborn (WT 1534); (b) and (d) are sections from its transgenic littermate Tg-g $\beta-1530$. Both animals were sacrificed directly after birth.

(a) Fused pinna.

(b) Nonfused pinna.

(c) Closed eyelid.

(d) Open eye fused pinnae, and cleft secondary palate-share several features that may hint at an underlying pathogenesis. A deficiency in the quantity of mesenchyme is associated with aberrant coordinate morphogenesis with the overlying epithelium. Embryonic fusion of these structures may be delayed as a result of inadequate mesenchymal proliferation or modeling, a process that normally serves to juxtapose adjacant elements in preparation for subsequent merger. Palate processes are formed in the primitive oral cavity. These swellings, composed of mesenchyme derived from migratory neural crest cells and covered by craniopharyngeal ectoderm, grow vertically, then elevate to appose opposite sides, and eventually fuse in the midline around day 15 (for review see Ferguson, 1988). Growth of the eyelids and pinnae occurs later in embryogenesis, with fusion between day 15 and day 17 (Maconnachie, 1979). In more caudal regions of the body, similar processes such as fusion of the digits and formation of the septum of the heart occur at similar times. These processes were not found to be affected in the transgenic animals.

A phenotype resembling that of ectopic Hox-1.1 expression, including open eyes at birth, cleft palate, and postnatal lethality, has been described for far mouse mutants (McLeod et al., 1980; Juriloff and Harris, 1983). However, our transgenic animals lack several features of far mutant animals, including facial skin tags and vibrissae abnormalities. On the other hand, detached pinnae are not a described finding in the far mutants. Depending on the genetic background, far is an incomplete dominant mutation and thus may represent a gain-of-function mutation (Juriloff et al., 1987). Further molecular and morphologi- cal examinations and comparisons between $\mathrm{g} \beta$ trans genic and far mice are under investigation.

Ectopic overexpression of the Drosophila genes Antp and Deformed leads predominantly to the alteration of anterior structures in transgenic flies (Gibson and Gehring, 1988; Kuziora and McGinnis, 1988). We observe a similar predominance in the transgenic mice. In addition, homeotic transformations such as ectopic legs or ectopic maxillary structures are induced in flies. To generate the homeotic phenotype, the timing and degree of ectopic expression must be precisely controlled. Experimentally induced ectopic expression of the pair-rule gene fush tarazu in segments not normally expressing this gene results in abnormal segmentation during development (Struhl, 1985). The experiments demonstrate that both expression and nonexpression are equally instructive in determining gene function, since the development of specific body regions requires selector genes to be induced or repressed in a combinatorial manner. In this study, homoeotic transformations could not be detected with the methods available. Rather, the transgenic phenotype is abnormal development of appropriate regional structures. The induction of specific developmental defects through ectopic expression of a mammalian Hox gene strengthens the assumption that these genes play an important role in the regulation of vertebrate embryogenesis.

\section{Neural Crest Cells as Possible Targets of Transgene Action}

The mesenchyme in all sites affected in the $\mathrm{g} \beta$ mice is partly (in the ear) or predominantly (in the palpebrae and palate) derived from the first arch neural crest (for review 

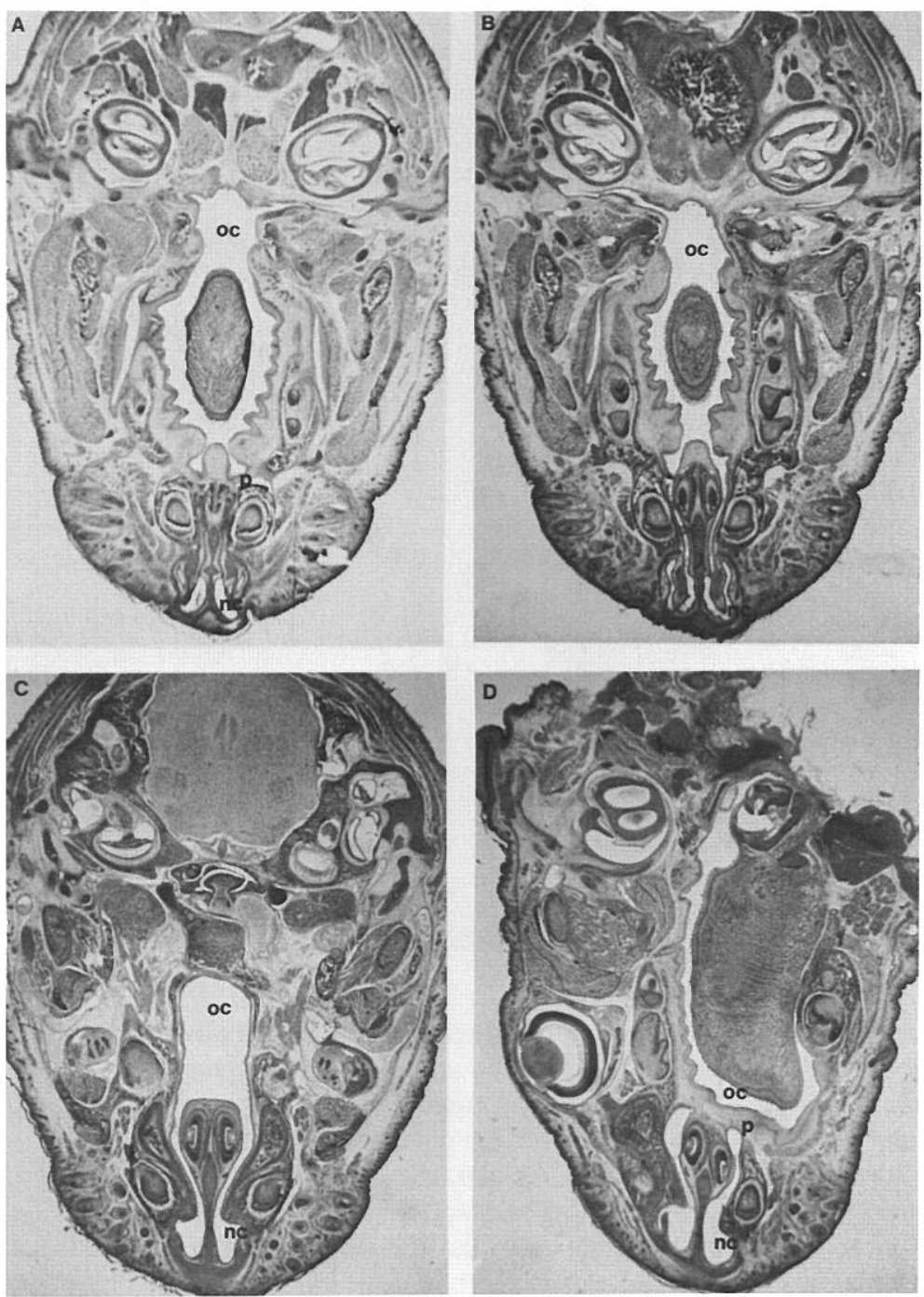

Figure 9. Histological Demonstration of Cleft Secondary Palate in a Transgenic Animal

(a)-(c) are sections from the transgenic animal $\mathrm{Tg}-\mathrm{g} \beta-1530$ representing the extremely rostral region (a) and more caudally located levels (b and c). (d) is a section from the nontransgenic littermate WT 1534 at a level comparable to (c). (a) Anterior separation of nasal (nc) and oral cavity (oc) by the primary palate (p).

(b) oc and nc no longer separated.

(c) Continuity of oc and nc as a result of cleft secondary palate.

(d) Separation of oc and nc by secondary palale (p). see Hall and Hörstadius, 1988; Ferguson, 1988; Noden and Van De Water, 1986). Neural crest cells originate from the dorsal ectoderm along each side of the neural plate during the final stage of neural tube closure. After migrating to their final position, they differentiate into a variety of different cell types (see Hall and Hörstadius, 1988). Cranial neural crest cells differ from trunk crest cells in having skeletogenic properties. The cells emigrating from the level of the rostral hindbrain normally contribute to structures of the first arch (Tan and Morriss-Kay, 1986). It is at present unclear whether neural crest cells show a predisposition toward a specific cell fate at the time of migration or whether they remain pluripotent until later stages of development. Several experiments indicate that at least some crest cells are pluripotent before migration from the neural tube (Hall and Hörstadius, 1988; BronnerFraser and Fraser, 1988), whereas transplantation experiments suggest that cranial neural crest cells are intrinsically predetermined at emigration (Noden, 1983). Our data indicate that cranial neural crest cells are possible targets of the ectopic Hox-1.1 gene expression. Determin- ing the specific step affected by the transgene may reveal important aspects of craniofacial development.

Up to now, few candidates for head selector genes have been identified. Most homeobox genes are not expressed rostral to the myelencephalon, except for the engrailedrelated genes En-1 and En-2, which are expressed in the complete central nervous system including the embryonic forebrain, or the mesencephalon, respectively (Davis and Joyner, 1988). Furthermore, the recently described Hox-7 gene is expressed in cranial neural crest cells and derived facial structures and thus is an interesting gene to study in the transgenic $\mathrm{g} \beta$ mice (Robert et al., 1989; Hill et al., 1989).

In Xenopus embryos microinjection of antibodies against a homeodomain protein (XIHbox1) resulted in absence of anterior dorsal root ganglia and deletion of the dorsal fin (Cho et al., 1988). The dorsal fin mesenchyme and the cervical dorsal root ganglia are derived from the neural crest, and removal of a small region of neural crest cells in amphibians leads to a loss of the dorsal fin (Hadorn, 1970). By increasing the gene dosage, the Hox- 
1.4 gene was specifically overexpressed in transgenic mice (Wolgemuth et al., 1989). The overexpression of Hox1.4 , although not ectopic, resulted in a functionally stenotic colon. It was postulated that Hox-1.4 overexpression affected neural crest-derived ganglia of the enteric nervous system. Thus these results, in addition to our own study, implicate neural crest cells as potential targets for Hox gene function.

\section{RAE Resembles the Transgenic Phenotype}

Vitamin A and its derivatives, the retinoids, have very important functions in vivo at physiological concentrations, whereas high doses of most retinoids are strongly teratogenic in vertebrates. RAE is characterized by severe limb and cranial defects, including cleft secondary palate, midfacial malformations, abnormal external and middle ear, and open eyes at birth (Shenefelt, 1972; Ferm and Ferm, 1979; Sulik et al., 1988). Women who took retinoic acid (Accutane) during pregnancy bore children with defects of the ear and craniofacial abnormalities (Lammers et al., 1985). In chicken, retinoid treatment in vivo specifically affected the upper but not the lower beak (Tamarin et al., 1984; Wedden et al., 1988). When 13-cis-retinoic acid was administered to mice, defects in the visceral arches were particularly prominent (Goulding and Pratt, 1986; Sulik et al., 1988). The phenotypes of $\mathrm{g} \beta$ mice and the far mutants are similar to RAE. The human syndrome mandibular dysostosis (Treacher Collins syndrome) also displays a similar phenotype (Sulik et al., 1988).

Since in vivo effects of retinoic acid suggested an effect on neural crest cells, in vitro experiments were performed that indeed demonstrated an inhibitory effect on migration of neural crest cells (Thorogood et al., 1982). Hassel et al. (1977) showed that retinol prevented the appearance of cranial neural crest cells in the first aortic arch of cultured chick embryos. It has been suggested that retinoids may interfere with positional cues that operate as facial primordia develop (Wedden et al., 1988).

Retinoic acid is a potential morphogen during the embryonic development of vertebrates, as recently supported by experimental evidence (Thaller and Eichele, 1987). In teratocarcinoma cells retinoic acid induces the expression of many homeobox-containing genes, including Hox-1.1 (Colberg-Poley et al., 1985a, 1985b; Breier et al., 1986; Kessel et al., 1987; Mavilio et al., 1988; Fibi et al., 1988). Furthermore, Deschamps et al. (1987) were able to correlate this induction strictly with the application of retinoic acid and not with the onset of differentiation. Thus the Hox genes may be induced by retinoic acid during embryogenesis. Our experiments pointed out similar consequences of systemic retinoic acid administration and ectopic Hox-1.1 expression during embryogenesis, suggesting a common mode of action. If it can be demonstrated that retinoic acid acts via an induction of Hox-1.1 in vivo, the similar phenotypes of RAE and our transgenic mice could be explained. The establishment of this correlation may help in understanding the teratogenic activity of retinoids and the physiological role of retinoic acid as a morphogen.

\section{Experimental Procedures}

\section{Expression Vector $g \beta$}

A 3899 bp genomic fragment spanning from the Xbal site $\mathbf{4 7 0}$ bp upstream of the main open reading frame of Hox-1.1 to an EcoRI site 417 bp downstream of the physiological poly(A) addition signal was inserted into the polylinker of the Bluescript vector (Stratagene). It was excised as a Xbal-Kpni fragment and inserted downstream of the chicken $\beta$-actin promoter. The recipient pUC18 plasmid contained the $\beta$-actin promoter as a Hinfl fragment spanning from position -330 to +10 . For microinjection the promoter-gene fusion was excised from the vector with Hindlll and Kpnl, gel purified, and passed over an Elutip column.

\section{Production of Tranegenic Mice}

NMRI outbred mice and C57BL/6/DBA/F1 mice were purchased from the Zentralinstitut für Versuchstierzucht, Hannover, FRG. Transgenic mice were produced essentially as described by Hogan et al. (1986). Six-week-old NMRI female mice were superovulated by injecting intraperitoneally $5 \mathrm{U}$ of gonadotropin from pregnant mare serum $48 \mathrm{hr}$ prior to injecting $5 \mathrm{U}$ of human chorionic gonadotropin. Female mice were then mated with C57BL6/DBA/F1 male mice. The next day, onecell-stage embryos were flushed from the oviducts of the mated female mice with M2 medium (Hogan et al., 1986). The eggs were freed of cumulus cells by hyaluronidase treatment. The male pronuclei of the fertilized eggs were microinjected with approximatly 2 pl of DNA at a concentration of $2 \mathrm{ng} / \mu \mathrm{l}$. The injected fertilized eggs were then transferred to pseudopregnant recipient NMRI female mice. Transgenic mice were identified by Southern blot analysis of DNA extracted from mouse tail biopsies as described by Hogan et al. (1986). The 1335 bp Xbal-BamHI fragment extending from the Xbal site in the $5^{\prime}$ untranslated region of Hox-1.1 (Figure 1) to a BamHI site in the intron was used as a probe.

\section{RNA Analysis}

Tissues were frozen in liquid nitrogen directly after dissection. Homogenization was achieved in concentrated guanidinium thiocyanate solution by using a Polytron homogenizer or shearing through syringe needles. RNA was purified according to Chirgwin et al. (1979).

Northern blotting and RNAase mapping were performed using standard methodology. Blots were hybridized with an oligolabeled probe prepared from a 187 bp EcoRl-Pvull fragment containing parts of the Hox-1.1 homeobox (Figure 1). To prepare labeled RNA for mapping of the transgenic RNA, a 365 bp Xhol-Xholl fragment spanning the $\beta$-actin-Hox-1.1 fusion site was subcloned into Bluescript. Correct initiation at the $\beta$-actin cap site should result in a protected RNA 90 bases long (Figure 1). To detect the Hox-1.1 homeobox-containing RNAs, an antisense RNA probe (434 bases) spanning from the Mstll site in the intron to the Pstl site $3^{\prime}$ of the box was hybridized, resulting in a protected RNA of 214 bases (Figure 1). As a positive control, identical amounts of RNA from TG-g $\beta-1183$ were analyzed in each experiment

\section{Histological Analysis}

Newborn mice were fixed for 2-3 days in Bouin's fixative and embedded in paraffin. Sections $(10 \mu \mathrm{m})$ were cut and then stained with hematoxylin and eosin

\section{Acknowledgments}

The authors would like to thank Merve Olowson, Carmen Kropp, Kirsten Schaub, and Sabine Geisendorf for excellent technical assistance and Ralf Altschäfel for photography. We thank Franz Theuring for his help with the DNA microinjection, Gregory Dressler and Andreas Püschel for constructive comments on the manuscript, and Bruce Paterson for providing the actin promoter. We are particularly indepted to Diane Juriloff and Muriel Harris (Vancouver) and Drew M. Noden (Ithaca) for helpful advice and suggestions. This work was supported by the Max-Planck Geselischaft.

The costs of publication of this article were defrayed in part by the payment of page charges. This article must therefore be hereby 
marked "advertisement" in accordance with 18 U.S.C. Section 1734 solely to indicate this fact.

Received February 27, 1989; revised April 17, 1989.

\section{Reterences}

Akam, M. (1987). The molecular basis for metameric pattern in the Drosophila embryo. Development 101, 1-22.

Balling, R., Deutsch, U., and Gruss, P. (1988). undulated, a mutation affecting the development of the mouse skeleton, has a point mutation in the paired box of Pax 1. Cell 55, 531-535.

Breier, G., Bucan, M., Francke, U., Colberg-Poley, A. M., and Gruss, $P$. (1986). Sequential expression of murine homeo box genes during $F 9$ EC cell differentiation. EMBO J. 5, 2209-2215

Bronner-Fraser, M., and Fraser, S. E. (1988). Cell lineage analysis reveals multipotency of some avian neural crest cells. Nature 335 , 161-164.

Chirgwin, J. M., Przybyla, A. E., MacDonald, R. J., and Rutter, W. J. (1979). Isolation of biologically active ribonucleic acid from sources enriched in ribonuclease. Biochemistry 18, 5294-5299.

Cho, K. W. Y., Goetz, J., Wright, V. E., Fritz, A., Hardwicke, J., and De Robertis, E. M. (1988). Differential utilization of the same reading frame in a Xenopus homeobox gene encodes two related proteins sharing the same DNA-binding specificity. EMBO J. 7, 2139-2149.

Colberg-Poley, A. M., Voss, S. D., Chowdhury, K., and Gruss, P. (1985a). Structural analysis of murine genes containing homeo box sequences and their expression in embryonal carcinoma cells. Nature 314, 713-718.

Colberg-Poley, A. M., Voss, S. D., Chowdhury, K., Stewart, C. L., Wagner, E. F., and Gruss, P. (1985b). Clustered homeo boxes are differentially expressed during murine development. Cell 43, 39-45. Colberg-Poley, A. M., Voss, S. D., Püschel, A. W., and Gruss, P. (1987). Post-transcriptional regulation of a murine homeo box gene transcript during F9 EC cell differentiation. Differentiation 35, 206-211.

Davis, C. A., and Joyner, A. L. (1988). Expression patterns of the homeo box-containing genes En-1 and En-2 and the proto-oncogene int-1 diverge during mouse development. Genes Dev. 2, 1736-1744.

Deschamps, J., De Laaf, R., Joosen, L., Meijlink, F., and Destree, O. (1987). Abundant expression of homeobox genes in mouse embryonal carcinoma cells correlates with chemically induced differentiation. Proc. Natl. Acad. Sci. USA 84, 1304-1308.

Deutsch, U., Dressler, G. R., and Gruss, P. (1988). Pax 1, a member of the paired box homologous murine gene family, is expressed in segmented structures during development. Cell 53, 617-625.

Dressler, G., and Gruss, P. (1988). Do multigene families regulate vertebrate development? Trends Genet. 4, 214-219.

Ferguson, M. W. (1988). Palate development. Development 103 (Suppl.), 41-60.

Ferm, V. H., and Ferm, R. R. (1979). Teratogenic interaction of hyperthermia and vitamin A. Biol. Neonate 36, 168-172.

Fibi, M., Zink, B., Kessel, M., Colberg-Poley, A. M., Labeit, S., Lehrach, $H$., and Gruss, P. (1988). Coding sequence and expression of the homeobox gene Hox 1.3. Development 102, 349-359.

Frischer, L. E., Hagen, F. S., and Garber, R. L. (1986). An inversion that disrupts the Antennapedia gene causes abnormal structure and localization of RNAs. Cell 47, 1017-1023.

Gehring, W. J., and Hiromi, Y. (1986). Homeotic genes and the homeobox. Annu. Rev. Genet. 20, 147-173.

Gibson, G., and Gehring, W. J. (1988). Head and thoracic transformations caused by ectopic expression of Antennapedia during Drosophila development. Development 102, 657-675.

Goulding, E. H., and Pratt, R. M. (1986). Isotretinoin teratogenicity in mouse whole embryo culture. J. Craniofac. Genet. 6, 99-112.

Guild, B. C., Finer, M. H., Housman, D. E., and Mulligan, R. C. (1988). Development of retrovirus vectors useful for expressing genes in cultured murine embryonal cells and hematopoietic cells in vivo. J. Virol. $62,3795-3801$
Hadorn, E. (1970). Experimentelle Entwicklungsforschung, im besonderen an Amphibien. Verständliche Wissenschaft, Band 77 (Berlin: Springer-Verlag).

Hall, B. K., and Hörstadius, S. (1988). The Neural Crest (London: Oxford University Press).

Hasselt, J. R., Greenberg, J. H., and Johnston, M. C. (1977). Inhibition of cranial neural crest cell development by vitamin $A$ in the cultured chick embryo. J. Embryol. Exp. Morphol. 39, 267-271.

Hill, R. E., Jones, P. F., Rees, A. R., Sime, C. M., Justice, M. J., Copeland, N. G., Jenkins, N. A., Graham, E., and Davidson, D. R. (1989). A new family of mouse homeo box-containing genes: molecular structure, chromosomal location, and developmental expression of Hox-7.1. Genes Dev. 3, 26-37.

Hogan, B., Costantini, F., and Lacy, E. (1986). Manipulating the Mouse Embryo (Cold Spring Harbor, New York: Cold Spring Harbor Laboratory).

Holland, P. W. H., and Hogan, B. L. M. (1988). Expression of homeo box genes during mouse development: a review. Genes Dev. 2 , 773-782.

Ingham, P. W. (1988). The molecular genetics of embryonic pattern formation in Drosophila. Nature 335, 25-34.

Jaenisch, R. (1988). Transgenic animals. Science 240, 1468-1474.

Juriloff, D. M., and Harris, M. J. (1983). Abnormal facial development in the mouse mutant first arch. J. Craniofac. Genet. 3, 317-337.

Juriloff, D. M., Harris, M. J., and Froster-Iskenius, U. (1987). Hemifacial deficiency induced by a shift in dominance of the mouse mutation far: a possible genetic model for hemifacial microsomia. J. Craniofac. Genet. $7,27-44$

Kessel, M., and Gruss, P. (1988). Open reading frames and translational control. Nature 332, 117-118.

Kessel, M., Schulze, F., Fibi, M., and Gruss, P. (1987). Primary structure and nuclear localization of a murine homeodomain protein. Proc. Natl. Acad. Sci. USA 84, 5306-5310.

Kuziora, M. A., and McGinnis, W. (1988). Autoregulation of a Drosoph ila homeotic selector gene. Cell 55, 477-485.

Lammer, E. J., Chen, D. T., Hoar, R. M., Agnish, A. D., Benke, P. J. Braun, J. T., Curry, C. J., Fernhoff, P. M., Grix, A. W., Lott, I. T., Richard, J. M., and Sun, S. C. (1985). Retinoic acid embryopathy. N. Engl. J. Med. 313, 837-841.

Leonard, J. M., Abramczuk, J. W., Pezen, D. S., Rutledge, R., Belcher J. H., Hakim, J. H., Shearer, G., Lamperth, L., Travis, W., Frederickson, T., Notkins, A. L., and Martin, M. A. (1988). Development of disease and virus recovery in transgenic mice containing HIV proviral DNA. Sclence 242, 1665-1670

Maconnachie, E. (1979). A study of digit fusion in the mouse embryo. J. Embryol. Exp. Morphol. 49, 259-276.

Mahon, K. A., Westphal, H., and Gruss, P. (1988). Expression of homeobox gene Hox 1.1 during mouse embryogenesis. Development 104 (Suppl.), 187-195.

Mansour, S. L., Thomas, K. R., and Capecchi, M. (1988). Disruption of the proto-oncogene int-2 in mouse embryo-derived stem cells: general strategy for targeting mutations to non-selectable genes. Nature 336, 348-353.

Mavilio, F., Simeone, A., Boncinelli, E., and Andrews, P. (1988). Activation of four homeobox gene clusters in human embryonal carcinoma cells induced to differentiate by retinoic acid. Differentiation 37, 73-79. McLeod, M. J., Harris, M. J., Chernoff, G. F., and Miller, J. R. (1980) First arch malformation: a new craniofacial mutant in the mouse. Hered. 71, 331-335.

Noden, D. M. (1983). The role of the neural crest in patterning of avian cranial skeletal, connective, and muscle tissues. Dev. Biol. 96, 144165

Noden, D. M., and Van De Water, T. R. (1986). The developing ear: tissue origins and interactions. In The Biology of Change in Otolaryngology, R. J. Reuben, T. R. Van De Water, and E. W. Rubel, eds. (New York: Excerpta Medica), pp. 15-46.

Robert, B., Sassoon, D., Jacq, B., Gehring, W. J., and Buckingham, M (1989). Hox-7, a mouse homeobox gene with a novel pattern of expression during embryogenesis. EMBO J. 8, 91-100 
Schneuwly, S., Klemenz, R., and Gehring, W. J. (1987). Redesigning the body plan of Drosophila by ectopic expression of the homeotic gene Antennapedia. Nature 325, 816-818.

Scott, M. P., and Carroll, S. B. (1987). The segmentation and homeotic gene network in early Drosophila development. Cell 51, 689-698.

Seiler-Tuyns, A., Eldridge, J. D., and Paterson, B. M. (1984). Expression and regulation of chicken actin genes introduced into mouse myogenic and nonmyogenic cells. Proc. NatI. Acad. Sci. USA 81, 2980-2984.

Shenefelt, R. E. (1972). Morphogenesis of malformations in hamsters caused by retinoic acid: relation to dose and stage at treatment. Teratology 5, 103-118.

Struhl, G. (1985). Near-reciprocal phenotypes caused by inactivation or indiscriminate expression of the Drosophila segmentation gene $f t z$. Nature 318, 677-680.

Sulik, K. K., Cook, C. S., and Webster, W. S. (1988). Teratogens and craniofacial malformations: relationships to cell death. Development 103 (Suppl.), 213-232.

Tamarin, A., Crawley, A., Lee, J., and Tickle, C. (1984). Analysis of upper beak defects in chicken embryos following treatment with retinoic acid. J. Embryol. Exp. Morphol. 84, 105-123.

Tan, S. S., and Morriss-Kay, G. M. (1986). Analysis of cranial neural crest cell migration and early fates in postimplantation rat chimaeras. J. Embryol. Exp. Morphol. 98, 21-58.

Thaller, C., and Eichele, G. (1987). Identification and spatial distribution of retinoids in the developing chick limb bud. Nature 327, 625-628.

Thompson, S., Clarke, A. R., Pow, A. M., Hooper, M. L., and Melton, D. W. (1989). Germ line transmission and expression of a corrected HPRT gene produced by gene targeting in embryonic stem cells. Cell $56,313-321$.

Thorogood, P., Smith, L., Nicol, A., McGinty, R., and Garrod, D. (1982). Effects of vitamin $A$ on the behaviour of migratory neural crest cells in vitro. J: Cell Sci. 57, 331-350.

Wedden, S. E., Ralphs, J. R., and Tickle, C. (1988). Pattern formation in the facial primordia. Development 103 (Suppl.), 31-40

Wolgemuth, D. J., Behringer, R. R., Mostoller, M. P., Brinster, R. L., and Paimiter, R. D. (1989). Transgenic mice overexpressing the mouse homeobox-containing gene Hox-1.4 exhibit abnormal gut development Nature 337, 464-467.

Zimmer, A., and Gruss, P. (1989). Production of chimaeric mice containing embryonic stem (ES) cells carrying a homeobox Hox 1.1 allele mutated by homologous recombination. Nature 338, 150-153. 